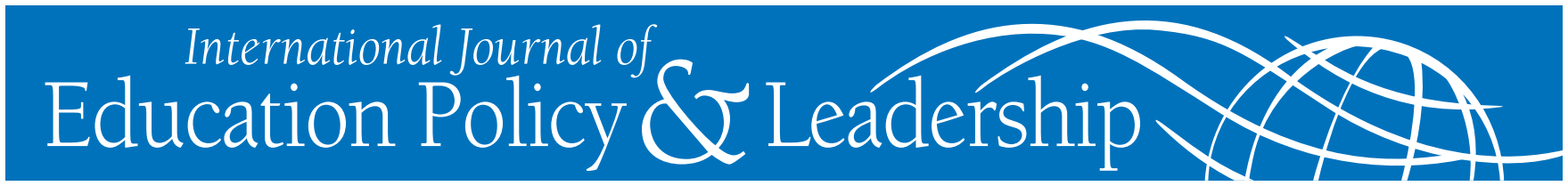

\title{
PARENTAl PARTICIPATION AND SCHOOl-BASED MANAGEMENT in NiCARAGUA: AN SES ANALYSIS OF DifFERENTIATED PARENT PARTICIPATION IN SCHOOL COUNCILS BY INCOME, EDUCATION, AND COMMUNITY CRIME RATES
}

\author{
MiCHAEL J. MCNAMARA \\ Brock University
}

\begin{abstract}
In Latin America, school-based management and decentralization have emerged as an important tool of education policy. The presumed benefits of school-based management designs depend, in large part, on broad parental participation in the programs that governments create to devolve decision making related to schooling. However, few studies examine the circumstances under which parents actually participate in newly established decentralized education programs. This article sheds partial light on these conditions by employing a socioeconomic status (SES) perspective to examine school-based management reform in Nicaragua. Using data derived from five newly autonomous schools, the study compares parents' self-reported levels of income, education, and community crime rates with their propensity to participate in newly formed school councils. Results give partial support to an SES hypothesis by revealing that parents who live in communities where violence is endemic participate less in the school councils. Findings support the argument that for decentralized education programs to be successful on equity issues, policy planners must attend to these socio-structural circumstances by providing commensurate support mechanisms that encourage marginal households and communities to participate in the new program.
\end{abstract}

McNamara, M. J. (2010). Parental Participation and Schoolᄀ-Based Management in Nicaragua: An SES Analysis of Differentiated Parent Participation in School Councils by Income, Education, and Community Crime Rates. International Journal of Education Policy and Leadership 5(7). Retrieved [date] from www.ijepl.org.

\section{Introduction}

School-based management (SBM) has emerged as an important instrument of education policy in Latin America over the last few decades. Since we are almost all advocates of participatory approaches to development in theory, one might think we should embrace SBM and decentralized educational programs more broadly as a method for improving school administration and student achievement in Latin America. In theory, SBM would mean that parents have a greater voice in school decision making, more direct control over policy decisions, and more direct access to policy decision makers (World Bank, 1999). In theory, this would mean that school programs, policies, and curricula could be tailored to local needs and specificities, with parents holding decision makers more accountable (Burki, Perry, \& Dillinger, 1999; Mohrman \& Wohlstetter, 1994).

However, an equally compelling case can be made that these reforms will disappoint their architects and intended beneficiaries. Specifically, in contrast to the SBM premise that participatory institutions can advance democratic values even in the case of social and material inequality, an alternative socioeconomic status (SES) model holds that social and material equality may be a necessary condition for fair, equal, and effec-

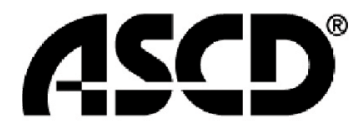

LEARN. TEACH. LEAD.
SIMON FRASER UNIVERSITY THINKING OF THE WORLD

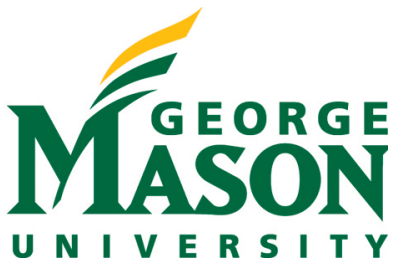


tive democratic deliberation (Wolfinger $\&$ Rosenstone, 1980; Verba \& Nie, 1972; Nie, Powell, \& Prewitt, 1969). More succinctly, the SES model posits income, education, and residential location-whether analyzed alone or in some combination,-as strong predictors of one's level of participation in democratic institutions (Conway, 1991; Nagel, 1987; Verba \& Nie, 1972).

In view of the recent policy shift towards decentralized education in Latin America, exploration of the influence of socioeconomic status on one's propensity to participate in decentralization educational programs is required. This information can help us understand how the benefits of decentralized educational programs are distributed across households and communities. This information can also sharpen the criticism against decentralization on equity issues and contribute to the ongoing debate surrounding empowered participation and decentralized education in the developing world.

\section{Purpose of the Study}

In this paper, we examine the relationship between socioeconomic status and parental participation in newly decentralized educational programs. We focus our attention on Nicaragua's New Law of Education Participation, which asks parents to contribute their resources by participating in local school councils. An SES hypothesis predicts that socioeconomic differences among individuals, if they exist but are unaccounted for in the program design, would influence levels of parental participation in autonomous school councils so as to privilege wealthier or better educated individuals while marginalizing less wealthy or less educated individuals in school deliberations (Agrawal \& Gupta, 2005; Hirschman, 1970). In the aggregate, an SES hypothesis might also imply that socioeconomic differences at the community level might generate sufficient levels of parental participation in school communities with wealthier, more educated, or generally better-off populations while failing to generate sufficient levels of participation in school communities defined by poverty, illiteracy, or marginalization (Bardhan, 2002). If the program benefits of decentralized decision making are thought to flow directly from increased parental participation, one could presume that a participatory deficit would offset the assumed gains of the reform (Agrawal \& Gupta, 2005).

The specific research question of the paper is: Does a primary caregiver's socioeconomic background predict her/his participation in autonomous school councils? To address this question, the study examines self-reports from parents and other primary caregivers from five schools in the Nicaraguan municipality of Matagalpa. Statistical procedures provide measures for the independent variables (income, education, and crime). The rationale for selecting these variables is discussed below. Descriptive statistics measure the dependent variables (levels of parental participation in school councils). To test the hypothesis that socioeconomic conditions influence one's propensity to participate in school councils, analysis of variance (ANOVA) examines school differences in both the independent and dependent variables. Next, discriminant functions analysis examines the relationship between independent and dependent variables within each school. Next, the same relationship within the general respondent population is examined, without controlling for schools. Finally, discriminant functions analysis considers the relative contributions of 'school' as an overarching variable predicting participation.

\section{Background}

Following the return of democracy to Nicaragua in 1990, the newly elected conservative government of Violetta Chamorro embarked on an ambitious project to reform primary and secondary schools in Nicaragua. The project, known as the Autonomous Schools Program (ASP), was exemplary of a prevailing neoliberal logic that argued that parents should be provided with an opportunity to influence school decisions through their votes and participation in local school councils (Gershberg, 2004). Under such an arrangement, it was argued, a better set of interests and information would be considered in school planning because parents are best positioned to diagnose problems and find pedagogic solutions to a school's specific learning and administrative problems (Burki, Perry, \& Dillinger, 1999). The ASP was also promoted as a means of depoliticizing education in Nicaragua because it took the power to hire school principals from the minister of education, a political appointee, and placed it directly in the hands of parents (Arcia \& 
Belli, 1999). As of 1993, a number of primary and secondary schools entered the autonomy program on a voluntary basis, with many more to follow over the next nine years. These new autonomous schools formed local school councils that were charged with decision-making authority over budget, personnel, and planning functions. The councils also had the authority to determine the level of fees charged to parents for attendance and/or examinations. The school council became the primary decision-making unit and consisted of elected representatives from the local community with parents having a strong voting majority (Gershberg, 2004; Arcia \& Belli, 1999).

In March 2002, the voluntary ASP was scaled up to cover all public schools through ratification of the New Law of Education Participation. The New Law effectively meant that all public schools in the country would be converted into autonomous schools by 2006, regardless of their willingness or managerial capacity to do so. While a number of government agencies, organizations, and independent researchers have evaluated the ASP, (see: Gershberg, 2004, 1999; Ministry of Education Nicaragua, 2004; Gunnarsson et al, 2004; Asensio, Ruiz and Sequeira, 2001; King, Ozler and Rawlings, 1999; Gershberg and Jacobs, 1998; Fuller and Rivarola, 1998) this knowledge is limited because it is informed by the study of schools that volunteered for the program or were handpicked by the ministry; in other words, schools that tended to be high-performing (Gunnarsson, 2004). This study provides a first look at how weaker schools (those neither handpicked nor willing to exert effort to become autonomous) are adapting to the demands of education decentralization in Nicaragua. This new information is important to ensure that the relative merits of the program are understood on the basis of a representative case sample. Results can also shed important light on whether we ought to adopt deliberative or participatory prescriptions without first equalizing the resources that stakeholders can deploy.

Aside from mandating autonomy for all public schools, there are several notable differences between the New Law and the ASP. First, the New Law clearly specifies the operational procedures for the school councils, which were lacking under the ASP. According to the New Law, parent representatives are to be elected by secret voting, with a quorum of 60 percent of parents. The elected representatives then form a parent council (consejo de padres). Similar associations are formed by elections among teachers (consejo docentes) and students (gobierno estudiantil). The elected parent, teacher, and student representatives and the school principal form the local school council (consejo directivo), with a voting majority of parent representatives. School councils have a range of powers, including the power to hire, fire, reprimand, and evaluate principals and teachers. They also have a range of decision-making power over administrative and planning functions and limited discretion over budget allocation. A second feature of the New Law is that it calls for community elections for the position of school principal. A third feature of the New Law is that it clearly states that school fees are to be voluntary, clarifying much of the confusion surrounding school fees under the ASP.

I examine the implementation and practice of the New Law in five schools from the municipality of Matagalpa. Located in the central highlands, it is the primary coffee-growing region of the country and a principle conflict zone of the civil war. Poverty, illiteracy, and crime characterize life in much of Matagalpa, particularly in the hillsides that surround the city. Matagalpa was selected as the investigation site because of this profile. Individual schools were selected for variation in SES characteristics. The names of schools have been changed to protect identities, but a description of each school is presented as accurately as possible.

I have given the five schools in this study the aliases "Santa Ana," "El Tuma," "La Dalia," "San Ramon," and "La Garita." All five schools fall within the jurisdiction of Matagalpa, but they differ in several respects. The first school, Santa Ana, displays conditions considered to be the most conducive for school autonomy within the sample. Santa Ana is located closest to the city's core. The data, discussed below, shows that Santa Ana is a relatively safe community and parents have, on average, a higher level of formal schooling than their counterparts in the sample. El Tuma shares many of the contextual characteristics that define Santa Ana. On average, parents have a higher level of formal education, more sufficient household incomes, and a comparatively better level of community security. This similarity is not surprising given that Santa Ana and El Tuma are located less than 10 blocks from one another. La Dalia is located on a hill overlooking the 
southern part of the city and is located about 25 blocks from the city's downtown core. Parents in this area have lower levels of formal schooling and lower household incomes than parents in the Santa Ana and El Tuma communities. San Ramon and La Garita are the most peripheral, located more than 15 kilometers from the city's downtown core. Both schools are located in the northern hills that surround the city of Matagalpa. In terms of the SES characteristics being considered in this study, La Garita stands as the most disadvantaged of the five sample schools. It is situated in a small mountain barrio on the outskirts of town and is the smallest school in the sample in terms of student enrollment. Crime is rampant in this community and parents generally rank the level of security in their community as "very poor or lacking." Comparatively, parents in this community also have the lowest average level of formal schooling.

\section{Theory: The SES Framework}

Previous research on political participation is characterized by the debate between three competing schools of thought; namely, the socio-structural school status (Conway, 1991; Nagel, 1987; Verba \& Nie, 1972), the political culture school (Putnam, 1995; Putnam et al. 1993; Dutch, 1993; Almond \& Verba, 1963), and the institutional school (North, 1990; Downs, 1957; Arrow, 1951). Each school of thought takes a different set of variables to be the main determinants of political participation. However, much of this research agrees that to explain participation it is important to consider economic and social factors at the household and community levels.

Some of the earliest work on political participation suggests that household income level has a significant effect on one's propensity to participate in democratic deliberation (Wolfinger \& Rosenstone, 1981; Acock \& Scott, 1980). One possible explanation for this is that low-income persons suffer from greater stress in general than people of higher SES do. Low-income individuals are more likely to experience personal problems, such as unemployment, and Dawson, Prewitt, and Dawson (1977) find that one's preoccupation with personal problems leads to a decline in political participation. This finding is also supported, in part, by Milgram's (1970) concept of overload, which refers to an individual's inability to process inputs from the en- vironment because there are too many inputs or inputs come too fast. When overload is present, the individual adapts by selectively attending to inputs and even ignoring some inputs altogether. In a highly stressful environment, political participation may decrease as other, more immediate demands for the individual's time and resources increase.

One's level of formal education has been shown as an important variable explaining propensity to participate in democratic deliberation. For example, Brady, Verba, and Scholzman (1995) show that individuals might not participate in politics because they lack the civic skills and vocabulary for involvement. On this account, formal education may confer upon individuals the skills and resources required for participating democratic deliberation. Simply stated, educated individuals are more likely to possess the cognitive and literacy skills required to absorb and process complex information required for democratic participation. Additionally, illiteracy may be an impediment to satisfying informational requirements for participation (Bardhan, 2003). This may mean that undereducated individuals want to participate, but lack the basic the skills for processing information even when it is made available to them (Verba, Scholzman, \& Brady, 2000).

Levels of community violence and crime may also be an important part of the explanation for why people participate in democratic deliberations and civic associations. This relationship may be explained, in part, by social capital arguments. For example, Hirschi's theory of antisocial behavior (1969) proposes that humans are equally predisposed to commit crime and that it is our social ties to others that inhibit antisocial behavior. In other words, social bonds serve as a deterrent to criminal behavior (Savage $\&$ Kanazawa, 2002). Likewise, in terms of political participation, a number of researchers have also found that communities with strong social bonds also show relatively higher levels of political participation (Putnam et al, 1995; Putnam, 1993; Verba \& Nie, 1972; Almond \& Verba, 1965). Community violence and crime rates may then be indicative of social bonds and social capital that are found to be predictors of political participation.

In terms of education research, several scholars have examined the relationship between social class and parental engagement in schooling. In her study of American elementary schools, Annette Lareau argues 
that social class, independent of a child's ability, exhibits a significant affect on children's lives in schools (2000). More specifically, Lareau demonstrates how social class influences levels of parental involvement in schooling and shapes the resources parents have at their disposal to comply with school requests for assistance. In a comprehensive analysis of America's system of public education, Richard Rothstein (2004) demonstrates the complex and ranging influence of social class on a child's academic performance. On the basis of this analysis, Rothstein argues that school improvements plans must be accompanied by broader reforms that mean to narrow the social and economic inequalities that produce gaps in student achievement.

Many studies of policy decentralization support these general arguments. For example, a number of case studies of decentralization initiatives have argued that the extent of local capture of the newly decentralized program by local elites depends, in part, on levels of social and economic inequality and traditions of political participation within the community (Conning \& Kevance, 2001; Crook \& Manor, 1998). Agrawal \& Gupta's (2005) study of Common Pool Resources in Nepal finds that the likelihood of participation in newly formed community-level user groups is greater for those who are economically and socially better off. Several studies of accountability reforms in education find that decentralization initiatives cannot realize their objectives unless targeted schools have, or acquire, the local capacity to meet the functional requirements and demands of the program (Malen $\&$ Rice, 2004; Fullan, 2001; Hess, 1999). In the context of Nicaragua's Autonomous Schools Program, Fuller and Rivarola (1998) find that, absent such local capacity building policies, school communities have greater difficulty negotiating and implementing clear and collectively held meanings of autonomy. Taken together, these studies support the position that SES indicators are likely to exhibit an important effect on one's propensity for participation in newly devolved participatory schooling programs (Nagel, 1987).

\section{Research Methodology}

The field research for this paper is part of a larger study designed to examine the form and practice of school autonomy in Matagalpa. The results and discussion presented here pertain to survey data collected for this larger project. The researcher spent 4 weeks in Matagalpa administering a 3-page survey consisting of 63 close-ended questions. Before administering the survey, the researcher conducted a pilot study surveying 1 principal, 18 teachers, and 22 parents from a trial school. Upon completing the trial survey, respondents were asked to comment on their comprehension of the survey. Using this information, the survey was modified and language translation issues were resolved with the assistance of local translators.

Having completed the pilot study, the researcher administered the final survey to 221 self-identified primary caregivers. To ensure that all caregivers could participate regardless of their literacy levels, the researcher read the survey to all participants. Participants were informed that their responses were completely confidential. It is assumed that respondents were open and honest when reporting, an assumption that can be seen as a limitation of the study. However, research has demonstrated that when respondents are assured of confidentiality, self-report measures have good validity (Singer, Von Thurn, \& Miller, 1995). Eighteen surveys were discarded or discontinued for various reasons, including: the respondent did not wish to continue the survey; the respondent repeatedly provided multiple answers to the same question; or the researcher felt that the participant was uncooperative. The participants in the present study are 204 selfidentified primary caregivers of primary and secondary students enrolled in one of the five schools. The participants include 151 mothers, 33 fathers, 8 grandmothers, 7 aunts, 2 uncles, and 3 other individuals who did not fall into these categories but selfidentified as the student's primary caregiver. The general sample population is divided into five corresponding school groupings, where Santa Ana consists of 73 respondents, El Tuma consists of 26 respondents, La Dalia consists of 28 respondents, San Ramon consists of 37 respondents, and La Garita consists of 40 respondents.

Survey questions revolve around variables found to be significant predictors of participation in previous research. In total, I included 11 variables. Variables, number of questions, scale, and example questions are illustrated in Table 1 (page 7). Our independent variables include the school, household income, parental level of education, and community crime rates. The first item, the school variable, is a nominal measure 
used to indicate the school in which the respondent's child is enrolled ( 1 = Santa Ana; $2=$ El Tuma; $3=$ La Dalia; 4= San Ramon; and 5= La Garita). "Income" is an ordinal measure used to assess the sufficiency of the respondent's household income levels using a 6-point scale ( $1=$ excellent to $6=$ very pessimistic). "Education" assessed the highest level of formal education the respondent achieved, using a 4-point scale ( $1=$ postsecondary to $4=$ less than primary). "Security" assessed how respondents viewed the level of security or level of violence in their own community, using a 5-point scale ( $1=$ excellent to $5=$ very pessimistic).

The dependent variables are presented in Table 1. The following questions were presented using a 2point scale ( $1=$ yes and $2=n o$ ). Parent Council Membership assessed if the respondent had ever been a member of the parent council. Parent Council Candidacy assessed if the respondent had ever been a candidate in an election for the parent council. Parent Council Elections assessed if the respondent had ever voted in an election for the parent council. Parent Council Participation assessed if the respondent had ever participated in a meeting a general meeting of the parent council. School Council Attendance assessed whether the respondent had ever attended a meeting of the general school council. Parent Council Knowledge was used to assess whether the respondent can identify current members of the parent council. In terms of interaction, the variable Parent Council Utilization assessed whether the respondent had ever spoken to a council member about education matters at the school.

\section{Findings and Discussion}

\section{Observations of Independent Variables: Socioeconomic Status}

Table 2 (page 8) reports means and standard deviations for the socioeconomic variables for the five schools. ANOVA reveals the schools are found to be statistically different in terms of education and highly statistically different in terms of community security/violence. A statistically significant between-group difference for income was not found $(F(2.202)=$ $1.314, \mathrm{p}=.266)$. The education variable is significant $(\mathrm{F}(2,202)=10.588, \mathrm{p}<0.001)$, reflecting a moderate difference between schools in terms of caregiver education levels. Post hoc analysis tests were conducted to examine which group means differ and how many group means differ. Tukey's B post hoc analysis reveals El Tuma, Santa Ana, and La Dalia as a homogenous subset group, to be distinguished from San Ramon and La Garita in terms of levels of caregiver education, where respondents in the first group report statistically higher levels of education than respondents in the second group. In terms of security, a statistically significant between-group difference was found for the security variable $(\mathrm{F}(202,2)=30.146, \mathrm{p}=<0.001)$. Tukey's $B$ post hoc analysis reveal three homogenous subgroups where Santa Ana form one subgroup of caregivers; El Tuma, La Dalia, and San Ramon form the second subgroup; and La Garita is distinguished as a third homogenous subgroup with the lowest ranked level of security in the sample.

The moderate statistical significance of the education variable and the high statistical significance of the security variable confirm that these school communities are differentiated by socioeconomic conditions pertaining to education and community security. The most striking aspect of these differences relates to the security variable, where the mean score for La Garita indicates that the vast majority of respondents are "very pessimistic" about the level of crime in their community. The researcher's experience in this community supports this finding. Specifically, several young men accosted this researcher outside the school following one day-visit. Additionally, taxis often refuse to enter the community during the evenings and most residents of Matagalpa warn visitors against traveling into the community at any time of the day.

Another interesting result relates to the income variable. The absence of statistically significant difference for the income variable indicates that household wealth is not part of the socioeconomic distinction of sample schools. However, mean scores for most schools fall within the range of average-to-deficient, La Garita being the exception with a mean score falling within the range of deficient-to-pessimistic.

Overall, the sample schools exhibit features characteristic of underdevelopment. First, participants in all five schools report levels of household income that are, on average, below the level of sufficiency. Second, participants in some schools-namely, La Garita and San Ramon-self-report levels of education that are, on average, only slightly better than a primary level. Third, these school communities are sharply distin- 
guished by levels of community violence and crime. Finally, the results reveal a trend whereby the poorer schools are also those with lower levels of adult educa- tion, higher rates of crime, and a greater distance from the city center.

Table 1: Description of Measures

\begin{tabular}{|c|c|c|c|}
\hline Measure & Items & Scale & Example of Questions \\
\hline \multicolumn{4}{|c|}{ School Measures } \\
\hline School & 1 & $\begin{array}{l}5 \text { point }(1=\text { school no. } 1 \text { to } \\
5=\text { school no. } 5 \text { ) }\end{array}$ & $\begin{array}{l}\text { What school does your child/ do your chil- } \\
\text { dren attend? }\end{array}$ \\
\hline \multicolumn{4}{|c|}{ Socioeconomic Measures (Independent Variables) } \\
\hline Income & 1 & $\begin{array}{l}6 \text { point }(1=\text { excellent to } 6= \\
\text { very pessimistic })\end{array}$ & $\begin{array}{l}\text { Is your household income sufficient to meet } \\
\text { your needs? }\end{array}$ \\
\hline Education & 1 & $\begin{array}{l}4 \text { point }(1=\text { post-secondary } \\
\text { to } 4=\text { less than primary) }\end{array}$ & $\begin{array}{l}\text { How many levels of formal education have } \\
\text { you completed? }\end{array}$ \\
\hline Security & 1 & $\begin{array}{l}5 \text { point }(1=\text { excellent to } 5= \\
\text { very pessimistic })\end{array}$ & $\begin{array}{l}\text { How would you rank the level of security in } \\
\text { your community? }\end{array}$ \\
\hline
\end{tabular}

Measures of Parental Participation in Councils (Dependent Variables)

Parent Council $1 \quad 2$ point $(1=$ no to $2=$ yes $) \quad$ Have you been a member of the parent counMembership cil?

Parent Council $1 \quad 2$ point ( $1=$ no to $2=$ yes $) \quad$ Have you ever been a candidate for election to Candidacy the parent council?

Parent Council $1 \quad 2$ point $(1=$ no to $2=y e s) \quad$ Have you ever voted in parent council elecElections tions?

Parent Council Par- 1

2 point $(1=$ no to $2=$ yes $)$

Have you ever participated in a parent council ticipation meeting?

Parent Council 1

2 point $(1=$ no to $2=$ yes $)$

Do you know who the current members of the Knowledge parent council are?

Parent Council $1 \quad 2$ point $(1=$ no to $2=$ yes $)$

Have you ever spoken to a member of the parUtilization ent council about the education of your child?

School Council $1 \quad 2$ point $(1=$ no to $2=$ yes $)$ Have you ever attended a meeting of the school Attendance council? 
Observations of Dependent Variables: Parental Participation

In terms of dependent variables, Table 3 (page 9) reports the frequencies and percentages of participant responses. Results are interesting in several respects. First, self-reports indicate that parent councils and school councils exist and are operating at all five schools. This is an impressive accomplishment given the challenges of mobilizing such a large number of people. The results are also impressive in that they indicate the majority of respondents have voted in an election for the parent council. Additionally, with the exception of La Dalia, the vast majority of respondents report having participated in a meeting of the parent council. The average respondent also appears to know a current member of the parent council. On these accounts, there appears to be little difference between schools.

Table 2: Means and Standard Deviations for Income, Education, and Security by School

\begin{tabular}{lllllll} 
Schools & Income & \multicolumn{3}{c}{ Education } & \multicolumn{3}{c}{ Security } \\
\hline & Mean & Std. Dev. & Mean & Std. Dev & Mean & Std. Dev. \\
Santa Ana & 3.67 & 1.791 & 2.07 & .869 & 1.89 & .871 \\
El Tuma & 3.61 & 1.270 & 1.88 & .833 & 3.00 & .978 \\
La Dalia & 3.71 & 1.761 & 2.12 & .909 & 2.62 & 1.299 \\
San Ramon & 3.88 & 1.513 & 2.59 & .832 & 3.10 & 1.221 \\
La Garita & 4.41 & 1.478 & 2.95 & .605 & 4.27 & 1.262 \\
\hline
\end{tabular}

However, participation is not a straightforward affair and we should not assume that attendance at council meetings is evidence of meaningful participation in council deliberations. For example, although 63 percent of survey respondents at La Garita reported having attended a parent council meeting, only 25 percent of the same respondents reported having spoken to a council member about their concerns. So, although parents may be attending parent council meetings, this does not necessarily mean that they use the council system to represent their concerns and advance their interests via deliberation with elected council representatives. Of course, alternative mechanisms for advancing interests may exist, but the results presented in Table 3 suggest that stakeholders do not always use the system of representation the New Law established for this purpose.

\section{The Relationship between Socioeconomic Status and Parental Participation within Individual Schools}

To test the SES hypothesis, I first use a discriminant functions analysis to examine the relationship between variables within each school. The security variable is not likely to have a statistically significant relationship within any of the dependent variables because it is a community-level variable and should therefore exhibit little variation between respondents from the same school. In Santa Ana, the education variable is found to be the only measure to successfully classify participants from nonparticipants. First, education is only moderately successful in classifying those who have been a candidate in parent council elections from those who have not $(\mathrm{F}(1,72)=5.501, \mathrm{p}=.022)$. Education is also moderately successful in classifying those who have attended a meeting of the general school council from those who have not $(F(1,72)=5.661$, 
$\mathrm{p}=.020$ ), suggesting those with more education are more likely to belong to the participant group. No other SES measure successfully distinguishes participant groups from nonparticipant groups in this case.

For El Tuma, La Dalia, and San Ramon, the SES measures do not distinguish participant groups from non-participant groups in any category with any degree of statistical significance. For La Garita, one's level of education is moderately successful in classifying those who have been members of the parent council from those who have not $(\mathrm{F}(1,39)=6.770, \mathrm{p}=.015)$. Additionally, measures for education moderately distinguish those who have attended a school council meeting from those who have not at La Garita (F $(1,39)=11.569, \mathrm{p}=.002)$.

Table 3: Response Frequency (Freq) and Percentages (\%) for Parental Participation by School Schools

\begin{tabular}{|c|c|c|c|c|c|c|c|c|c|c|c|}
\hline \multirow[t]{2}{*}{ Variable } & \multirow[t]{2}{*}{ Response } & \multicolumn{2}{|c|}{ Santa Ana } & \multicolumn{2}{|c|}{ El Tuma } & \multicolumn{2}{|c|}{ La Dalia } & \multicolumn{2}{|c|}{ San Ramon } & \multicolumn{2}{|c|}{ La Garita } \\
\hline & & Yes & No & Yes & No & Yes & No & Yes & No & Yes & No \\
\hline \multirow{2}{*}{ Membership } & Freq & 18 & 55 & 4 & 22 & 7 & 20 & 7 & 30 & 8 & 32 \\
\hline & $\%$ & 25 & 75 & 15 & 86 & 25 & 72 & 19 & 81 & 20 & 80 \\
\hline \multirow{2}{*}{ Candidacy } & Freq & 34 & 39 & 8 & 18 & 8 & 19 & 15 & 20 & 14 & 23 \\
\hline & $\%$ & 47 & 53 & 31 & 69 & 29 & 68 & 40 & 54 & 35 & 57 \\
\hline \multirow{2}{*}{ Elections } & Freq & 56 & 17 & 20 & 6 & 21 & 6 & 23 & 11 & 33 & 7 \\
\hline & $\%$ & 77 & 23 & 77 & 23 & 75 & 22 & 62 & 30 & 83 & 17 \\
\hline \multirow{2}{*}{ Participation } & Freq & 58 & 15 & 20 & 6 & 8 & 18 & 28 & 9 & 25 & 14 \\
\hline & $\%$ & 80 & 20 & 77 & 23 & 29 & 64 & 70 & 24 & 63 & 35 \\
\hline \multirow{2}{*}{ Knowledge } & Freq & 66 & 7 & 20 & 6 & 15 & 10 & 23 & 11 & 19 & 19 \\
\hline & $\%$ & 90 & 10 & 77 & 23 & 54 & 36 & 62 & 30 & 50 & 50 \\
\hline \multirow{2}{*}{ Utilization } & Freq & 59 & 14 & 10 & 16 & 11 & 15 & 21 & 13 & 10 & 30 \\
\hline & $\%$ & 81 & 19 & 39 & 62 & 39 & 54 & 57 & 35 & 25 & 75 \\
\hline \multirow{2}{*}{ Attendance } & Freq & 50 & 22 & 9 & 17 & 10 & 17 & 21 & 15 & 9 & 31 \\
\hline & $\%$ & 69 & 30 & 35 & 65 & 36 & 61 & 57 & 41 & 22 & 78 \\
\hline
\end{tabular}

On the basis of these findings, there is limited evidence of a relationship between SES characteristics and participation within schools. Education is the only variable to successfully classify participant from nonparticipant groups, but the findings are limited to certain participatory practices (council membership and council meeting attendance) and to only two schools. Additionally, the strength of the relationship between education and participatory practices is moderate.
Drawing on the evidence presented here, the SES hypothesis is not supported.

The Relationship between Socioeconomic Status and Parental Participation within the General Population

A third test considers the relationship within the general population. On this account, there is no control 
for schools. Discriminant functions analysis finds that only the security variable lends strong and consistent support to the SES hypothesis. Specifically, the security variable is moderately successful in classifying those who have participated in a parent council meeting from those who have not $(F(1,203)=10.143$, $\mathrm{p}=.002$ ). Security is also moderately successful in classifying those who know the current member of their parent council from those who do not $(F(1,203)=$ $13.778, \mathrm{P}<.001)$. The security measure is highly successful in classifying those who have spoken to a council member about their child's education from those who have not $(\mathrm{F}(1,203)=30.155, \mathrm{P}<.001)$. The security variable is also highly successful in classifying those who have attended a meeting of the general school council from those who have not (school council attendance $)(F(1,203)=7.997, \mathrm{p}=.005)$.

The finding that security relates to participation is interesting and requires further investigation. In communities characterized by such extreme levels of crime, parents might not risk personal safety by traveling unnecessarily during mid-to-late afternoons and early evenings to attend council meetings regularly. This cost-benefit calculation might explain the lower levels of parental participation at parent council meetings at La Garita and, to some extent, San Ramon. An alternative explanation is implied by Hirschi's (1969) theory of anti-social behaviour, which suggests high levels of crime are indicative of weak social bonds within the community. Putnam (1993; 1995) famously found social bonds to be strong predictors of political participation and, on this 'social capital' account, communities like La Garita could suffer a participation deficit because of weak social ties or social bonds. This account could explain the higher rate of crime in La Garita as well as the community's participatory deficits in the council system. Finally, a third explanation might be that the security variable itself reflects something other than community security or crime rates. To illustrate, consider that La Garita is the poorest, least safe, and most remote school community in the sample. It is difficult to get to and many taxis refuse to enter the area at night. Under such conditions, it is not hard to imagine that the principal at La Garita must find it difficult to recruit and retain qualified teachers. Thus, it is conceivable that the relationship may be due to a host of factors related to crime, such as lowquality staff, rather than crime itself.

\section{The Relationship between School and Pa- rental Participation within the General Population}

A fourth test is conducted using "the school" as a nonspecific, overarching variable that, in all likelihood, encompasses multiple factors. Although one cannot speak about this variable with any precision, examining a relationship between the school and indicators of parental participation in school councils may shed important light on the nature of education decentralization in Matagalpa. In this test, the school variable is highly successful in distinguishing those who know their council representatives from those who don't (F $(1,203)=21.648, \mathrm{P}<.001)$. School is also a very helpful measure for distinguishing those who have spoken to council members about their concerns from those who have not $(\mathrm{F}(1,203)=21.625, \mathrm{P}<.001)$. Finally, school is also a successful measure for distinguishing those who have attended a meeting of the general school council from those who have not $(F(1,203)=12.041$, $\mathrm{p}=.001$ ).

This finding clearly shows that participation is likely to vary between schools exposed to the same policy treatment. While we cannot be sure about the reasons for this finding, it is very significant for the decentralization debate because it implies that the practice of decentralization depends on something other than the legislated policy itself. In this study, we have suggested that parental education, crime rates, and social bonds may be part of this explanation, but much more work in this area is required. However, this finding is a clear warning against the universal application of decentralized programs in education.

\section{Conclusion and Policy Recommen- dations}

Drawing on certain social assumptions about the paramount importance of individualism and the need to encourage choice, the main focus of education decentralization programs is the empowerment of individual households rather than resource redistribution, income maintenance, or capacity-building measures (Penn, 2002). This study began by asking, "Does a parent's socioeconomic background predict their participation in their autonomous school council?" Results suggest a need to refocus attention and effort on 
structural inequities that prevent parents from participating in ways predicted by decentralization architects.

First, the study challenges conventional wisdom by showing that parental participation in decentralization initiatives varies among communities exposed to the same policy treatment. On this account, this study should be read alongside previous work reaching similar conclusions (Wylie, 1999). Second, the study highlights a critical distinction between de jure autonomy (the passage of reform legislation) and de facto autonomy (the actual practice of school autonomy in schools) (Gunnarsson, 2004) and highlights the need to explain the difference. Third, observed differences in the participatory practices of stakeholders caution against using narrow definitions of participation, such as attendance at meeting, but rather point to a reality of participation in decentralized programs that is both complex and multi-faceted.

Of course, a compelling aspect of these findings is that they beg an answer to the question of how to explain participatory differences between households and communities. On this account, partial support for an SES explanation is found. While there is little discernable evidence to suggest that household income and levels of education are directly responsible for observable differences, some evidence that community crime rates may, in part, predict participatory differences between school communities has been offered. The nature of the relationship between crime, violence, and participation is far from clear. Possible explanations for these observations may include individual cost-benefit problems, the inability of these schools to attract and retain quality staff, and social capital deficiencies. Nevertheless, the warnings are significant. By proceeding with education decentralization without considering the influence of SES characteristics, programs may produce a two-pronged effect. First, they can overburden school staff with new administrative responsibilities without commensurate support from the wider community. Second, if a participatory deficit exists, these programs can open the door for corruption and program capture because parents are not involved in sufficient numbers to hold decision-makers accountable (Bahiigwa, Rigby, \& Woodhouse, 2005; Francis \& James, 2003; Bardhan, 2002).

To conclude, this study has made the case that stakeholder participation in decentralized educational programs is contingent on factors beyond the legis- lated policy itself. The first step towards improving decentralized education programs is to find out what these contingent factors are. To some extent, an SES model is useful in identifying these factors, but much more research in this area is required. However, if we are to make meaningful headway, policy planners and researchers alike must abandon individualistic models that deny the socio-structural characteristics that define households and school communities in the developing world. Only when these circumstances are understood as barriers to parental participation in decentralized educational programs, will we have a sufficient model of participation and its determinants. Only when these circumstances are accounted will it be possible to meet the objective of distributing the benefits of decentralized programs in an equitable and democratic fashion.

\section{References}

Acock, A. C., \& Scott, W.J. (1980). A model for predicting behaviour: The effect of attitude and social class on high and low visibility political participation. Social Psychology Quarterly, 43, 59-72.

Agrawal, A., \& Gupta, K. (2005). Decentralization and participation: The governance of common pool resources in Nepal's Terai. World Development, 33(7), 1101-1114.

Almond, G.A., \& Verba, S. (1963). The civic culture: Political attitudes and democracy in five nations. Princeton: Princeton University Press.

Arcia, G., \& Belli, H. (1999). Rebuilding the social contract: School autonomy in Nicaragua. Washington, D.C.: The World Bank, Latin America and the Caribbean Regional Office.

Arrow, K. (1951). Social choice and individual values. New Haven: Yale University Press.

Bahiigwa, G., Rigby, D., \& Woodhouse, P. (2005). Right target, wrong mechanisms? Agricultural modernization and poverty reduction in Uganda. World Development, 33(3), 481-496.

Bardhan, P. (2002). Decentralization of governance and development. The Journal of Economic Perspectives, 16(4), 185-205.

Beals, R. L. (1953). Social stratification in Latin America. University of Chicago Press. 
Brady, H., Verba, S., \& Schlozman, K.L. (1995). Beyond SES: A resource model of political participation. American Political Science Review, 89(2), 271-294.

Burki, S.J., Perry, G., \& Dillinger, W. (1999). Beyond the center: Decentralizing the state. Washington, D.C.: The World Bank.

Conning, J., \& Kevane, M. (2001). Community based targeting mechanisms for social safety nets. Washington, D.C.: The World Bank.

Conway, M. (1991). Political participation in the United States, 2nd edition. Washington, D.C.: Congressional Quarterly Press.

Crook, R., \& Manor, J. (1998). Democracy and decentralization in South Asia and West Africa. Cambridge: Cambridge University Press.

Dawson, R.E., Prewitt, K., \& Dawson, K.S. (1977). Political socialization. Boston: Little-Brown.

Downs, A. (1957). An economic theory of democracy. New York: Harper.

Dutch, R. M. (1993). Tolerating economic reforms: Popular support of transition to a free market in the former Soviet Union. American Political Science Review, 87(3), 590-608.

Foro Sobre Decentralizacion y Participacion Social en las Escuelas. (2002). El futuro de reforma educativa en Nicaragua. Managua, Nicaragua.

Francis, P., \& James, R. (2003). Balancing rural poverty reduction and citizen participation: The contradictions of Uganda's decentralization program. World Development, 31(2), 325-337.

Fullan, M. (2001). The new meaning of educational change, 3rd edition. New York: Teachers College Press.

Fuller, B. \& Rivarola, M. (1998). Nicaragua's experiment to decentralize schools: Views of parents, teachers, and directors. Working Paper Series on Impact Evaluation of Education Reforms, Paper No. 5. Washington, D.C.: The World Bank.

Gershberg, A. I. (2004). Empowering parents while making them pay: Autonomous schools and education reform processes in Nicaragua. In R. R. Kaufman \& J. M. Nelson, eds., Crucial needs, weak incentives: The politics of health and education reform in Latin America, Woodrow Wilson Center Press with Johns Hopkins University Press.
Gershberg, A. I. (1999). Decentralization, citizen participation, and the role of the state: The autonomous schools program in Nicaragua. Latin American Perspectives, 26(4), 8-38.

Gershberg, A.I., \& Jacobs, M. (1998). Decentralization and recentralization: Lessons from the social sectors in Mexico and Nicaragua. Inter-American Development Bank Working Paper \#379. Washington, D.C.: Inter-American Development Bank.

Gunnarsson, V., Orazem, P., Sanchez, M., \& Verdisco, A. (2004). Does school decentralization raise student outcomes? Theory and evidence on the roles of school autonomy and community participation. Department of Economics Working Paper Series, Working paper \#04005. Iowa: Iowa State University.

Hess, G. A. (1999). Expectations, opportunity, capacity and will: The four essential components of Chicago school reform. Educational Policy, 13, 494-517.

Hirschi, T. (1969). Causes of delinquency. Berkeley: University of California Press.

Hirschman, A. O. (1970). Exit, voice, and loyalty: Responses to declines in firms, organizations, and states. Cambridge: Harvard University Press.

Inter-American Development Bank (1999). Facing up to inequality in Latin America: 1998-99 Report. Washington: Inter-American Development Bank and The John Hopkins University Press.

Kagan, J. (1998). Three Seductive Ideas. Cambridge, MA: Harvard University Press.

King, E., Ozler, B., \& Rawlings, L. (1999). Nicaragua's school autonomy reform: Fact or fiction? Paper No. 19. Working Paper Series on Impact Evaluation of Education Reforms, Development Research Group. Washington, D.C.: The World Bank.

Lareau, A. (2000). Home advantage: Social class and parental intervention in elementary education, 2nd edition. Lanham, MD: Rowman and Littlefield Publishers, Inc.

Malen, B. \& Rice, J. K. (2004). A framework for assessing the impact of education reforms on school capacity: Insights from studies of high stakes accountability initiatives. Educational Policy, 18(5), 631-660.

Milgram, S. (1970). The experience of living in cities. Science, 167, 1461-1468 
Ministry of Education, Nicaragua (2004). Plan Operativo Annual 2005: Por una Nicaragua mas educada y preparada para ser gestora de su propio desarrollo. Managua, Nicaragua: Ministry of Education.

Mohrman, S., \& Wohlstetter, P. (1994). School-based management: Organizing for high performance. San Francisco: Jossey-Bass.

Nagel, J. H. (1987). Participation. New Jersey: Prentice Hall.

Nie, N., Powell, G. B., \& Prewitt, K. (1963). Social structure and political participation: Developmental relationships. American Political Science Review, 63(2), 361-378 (Part 1) and 63(4), 808-832 (Part 2).

North, D. (1990). Institutions, institutional change, and economic performance. New York: Cambridge University Press.

Penn, H. (2002). The World Bank's view of early childhood. Childhood, 9(1), 118-132.

Putnam, R. D., Leonardi, R., \& Nanetti, R. Y. (1993). Making democracy work. Princeton: Princeton University Press.

Putnam, R. D. (1995). Bowling alone: America's declining social capital. Journal of Democracy, 6(1), 67-78.

Rothstein, R. (2004). Class and schools: Using social, economic, and educational reform to close the black-white achievement gap. Washington, D.C.: Economic Policy Institute.

Savage, J., \& Kanazawa, S. (2002). Social capital, crime, and human nature. Journal of Contemporary Criminal Justice, 18(2), 188-211.

Singer, E., Von Thurn, D. R., and Miller, E. R. (1995). Confidentiality assurances and response: A quantitative review of the experimental literature. Public Opinion Quarterly, 59, 66-77.

Verba, S., Schlozman, K. L., \& Brady, H. E. (2000). Rational action and political activity. Journal of Theoretical Politics, 12(3), 243-286.

Verba, S., \& Nie, N. (1972). Participation in America. New York: Harper and Row.
World Bank (2002). EDSTATS. Washington, D.C.: The World Bank.

Wolfinger, R., \& Rosenstone, S. (1980). Who Votes? New Haven: Yale University Press.

Wylie, C. (1999). Ten years on: How schools view educational reform. Wellington: New Zealand Council on Educational Research.

IJEPL is a joint publication of the Association for Supervision and Curriculum Development, the Faculty of Education at Simon Fraser University, and the College of Education and Human Development at George Mason University. By virtue of their appearance in this open access journal, articles are free to use, with proper attribution, in educational and other non-commercial settings 90 days after initial publication. Copyright for articles published in IJEPL is retained by the authors. More information is available on the IJEPL Web site: http://www.ijepl.org 